\title{
COST-EFFECTIVENESS ANALYSIS OF THE ANALGESIC THERAPY OF POSTOPERATIVE PAIN
}

\author{
Silvia Regina Secoli ${ }^{1}$ \\ Kátia Grillo Padilha ${ }^{2}$
}

Júlio Litvoc ${ }^{3}$

Secoli SR, Padilha KG, Litvoc J. Cost-effectiveness analysis of the analgesic therapy of postoperative pain. Rev Latino-am Enfermagem 2008 janeiro-fevereiro; 16(1):42-6.

The study aimed to compare cost-effectiveness of analgesic schemes administered to 89 patients submitted to hemorrhoidectomy, on the 1st postoperative day. The descriptive and retrospective study was carried out in a General Hospital, Sao Paulo, Brazil. In order to carry out the cost-effectiveness analysis, the five most frequently used analgesic schemes were identified in practice. The main outcome was the absence of breakthrough pain episodes. While calculating the costs, analgesics and all devices related to the schemes were taken into consideration. Codeine $120 \mathrm{mg}+$ acetaminophen $2000 \mathrm{mg}$ was the most effective therapy with the lowest cost per patient with no breakthrough pain episodes (\$65.23). Incremental analysis indicated that codeine $120 \mathrm{mg}+$ acetaminophen $2000 \mathrm{mg}+$ ketoprofen $200 \mathrm{mg}$ involved the additional cost of $\$ 238.31$ in case an extra effectiveness benefit was needed. The analysis showed that the most suitable choice of analgesic therapy should consider the resources available at the institution along with economic and clinical aspects.

DESCRIPTORS: health economics; health evaluation; postoperative pain; analgesics

\section{ANÁLISIS DE COSTO-EFECTIVIDAD EN EL TRATAMIENTO ANALGÉSICO PARA DOLOR POST-OPERATORIO}

El presente estudio utilizó el análisis de costo-efectividad para comparar los esquemas analgésicos administrados en 89 pacientes sometidos a hemorroidectomía, durante el 10 día del post-operatorio. Estudio descriptivo y retrospectivo realizado en el Hospital General de São Paulo. Para efectuar este análisis se identificaron los ${ }^{5}$ esquemas analgésicos más utilizados por el servicio. El efecto principal fue la ausencia de dolor. Para calcular los costos fueron incluidos los analgésicos y los materiales utilizados para la administración. El esquema codeína $120 \mathrm{mg}+$ acetaminofen $2000 \mathrm{mg}$ fue más efectivo, siendo de menor costo para el paciente sin dolor (\$65,23). Este incremento mostró que la mezcla codeína 120 mg+acetamenofen 2000mg+ cetoprofeno $200 \mathrm{mg}$ tuvo un costo adicional de \$238,31 para poder obtener un beneficio extra de efectividad. A través del análisis, la selección del esquema analgésico requiere además de ser económico y clínico, la disponibilidad de recursos de la propia institución.

DESCRIPTORES: economía de la salud; evaluación en salud; dolor post-operatoria; analgésicos

\section{ANÁLISE CUSTO-EFETIVIDADE DA TERAPIA ANALGÉSICA UTILIZADA NA DOR PÓS- OPERATÓRIA}

No presente estudo realizou-se a analise custo-efetividade para comparar esquemas analgésicos administrados a 89 pacientes submetidos a hemorroidectomia, no 10 dia de pós-operatório. Trata-se de um estudo descritivo e retrospectivo realizado em Hospital Geral de São Paulo. Para realização da análise custoefetividade identificou-se os ${ }^{5}$ esquemas analgésicos mais utilizados na clinica. O principal desfecho foi ausência de escapes de dor. No cálculo dos custos foram considerados os analgésicos e dispositivos associados à administração. O esquema codeina $120 \mathrm{mg}+$ acetaminofeno $2000 \mathrm{mg}$ mostrou-se mais custo-efetivo, apresentando o menor custo por paciente sem escape de dor $(\$ 65,23)$. A análise incremental apontou que o padrão codeína $120 \mathrm{mg}+$ acetamenofeno $2000 \mathrm{mg}+$ cetoprofeno $200 \mathrm{mg}$ apresentou um custo adicional de $\$ 238,31$ para se obter um benefício extra de efetividade. A análise mostrou que a escolha do esquema analgésico deve contemplar, além dos aspectos econômicos e clínicos das opções terapêuticas, a disponibilidade de recursos da instituição.

DESCRITORES: economia da saúde; avaliação em saúde; dor pós-operatória; analgésicos

${ }^{1}$ RN, Ph.D., Faculty, e-mail secolisi@usp.br; ${ }^{2}$ RN, Associate Professor, e-mail kgpadilh@usp.br. University of São Paulo School of Nursing, Brazil; ${ }^{3}$ Sanitarian Physician, Ph.D., University of São Paulo Medical School, Brazil, e-mail: julitivoc@usp.br 


\section{INTRODUCTION}

A mong the current concerns of health professionals involved in the control of pain, two topics have been considered of importance in the worldwide literature: postoperative ( $\mathrm{PO}$ ) pain and the costeffectiveness analysis (CEA) of analgesic interventions. The former is important for its epidemiological relevance and the latter because of the repercussions of economic questions on clinical practice and because of the search for efficiency in the health system.

$\mathrm{PO}$ pain is one of the most prevalent types of acute pain and is an expected result of surgical procedures experienced by thousands of patients all over the world ${ }^{(1)}$. PO pain manifests in a moderate or intense manner in $40 \%$ to $60 \%$ of cases for more than $50 \%$ of the time ${ }^{(2)}$. Its somatic and psychic expression may be directly or indirectly associated with increased morbidity and mortality, with consequent social and economic repercussions. Thus, over the last decades this organic manifestation has gained the dimensions of a world public health problem $^{(3)}$.

In developed countries, the interest in the economic aspects of analgesia applied during the PO period is recent and has been concentrated on highcost treatments, especially in view of the use of new technologies in the management of discomfort ${ }^{(4-6)}$. A single study is available din Brazil in which the author compared to costs and outcomes of different analgesic methods in patients submitted to different types of surgery $^{(7)}$.

However, although scarce, some studies of CEA were found in which the authors compared the PCA method to the classical method of intramuscular morphine administration in patients submitted to gynaecological surgery ${ }^{(5)}$. Authors analyzed analgesic therapy in patients with fractured limbs by comparing ketorolac and morphine ${ }^{(8)}$. It should be pointed out that in the cited studies the results of the analyses were not expressed in terms of cost per clinical success unit, one of the basic assumptions that indeed characterize the CEA. The results of the CEAs are expressed by a quotient in which the numerator is the cost and the denominator is the effectiveness ${ }^{(9-10)}$.

Thus, considering that the CEA requires the quantification and association of costs and outcomes of the interventions and medications, with the costs being measured in monetary units and the effectiveness in clinical units, in order to assess the impact of different alternatives and to permit the improvement of the effects of treatment in exchange for the use of more resources, we must say that the world literature presents a large gap with respect to this topic ${ }^{(9)}$.

In view of the above considerations and of a scenario in which the practice and the technical decisions of health professionals are increasingly tied to economic restrictions, the objective of the present study was to carry out a cost-effectiveness analysis of the analgesic schemes used for surgical patients on the first PO day (1stPO).

\section{SAMPLE AND METHODS}

The sample consisted of 89 patients submitted to hemorrhoidectomy at a medium-sized private general hospital located in the municipality of São Paulo, Brazil. The study was conducted on adults aged up to 60 years, submitted to elective hemorrhoidectomy by the closed method and by the technique of Ferguson performed by the same coloproctology team. On the 1stPO the patients received nonsteroidal anti-inflammatory analgesics (NSAID) or opioid analgesics (OA), or both, prescribed according to a regular time schedule (SRT), or OA prescribed a pro re nata (PRN). Patient age ranged from 20 to 60 years (mean $=44.36$; median 44 and SD $=9.63)$, $56.0 \%$ were females, $73.0 \%$ were classified as ASA I, and $59.0 \%$ were submitted to general anesthesia.

Data were collected from the medical records of the patients after authorization by the Medical Ethics Committee of the Hospital. After the data concerning analgesic therapy and outcomes were obtained from the records, the official price list of drugs and disposable material for the state of São Paulo were consulted ${ }^{(11)}$ and the Departments of Human Resources of various hospitals were contacted in order to estimate the costs of the analgesic schemes.

For the cost estimates of therapeutic schemes, we computed the direct costs of the analgesics (unitary cost), of disposable material (needles, syringes, diluent specified), of the maintenance of venous access (venous catheter, heparin, luer lock), and of the time spent by the 
nursing team to administer the medications (the labor costs is the average salary and benefits of the person who handles the drug multiplied by the number of minutes the drug was handled). The unity monetary was american dollar (US\$) in order to be possible comparisons among international studies.

The measurement of the effectiveness of analgesic schemes was based on criteria: breakthrough pain episodes. For this purpose, breakthrough pain was defined as the complaints of pain reported by the patients during the $\mathrm{PO}$ period. According to this criterion, the effectiveness (E) of the analgesic schemes was measured in terms of number of patients who did not present breakthrough pain over the $24 \mathrm{~h}$ of the 1stPO (NPP) divided by the total number of patients treated with the scheme (NTS) $-\mathrm{E}=\mathrm{NPP} / \mathrm{NTS}$

For the analysis of the cost of the analgesic scheme we used the decision tree model which contemplated the successes (only SRT) and the failures (SRT + PRN) that occurred, considering the probability of occurrence of the two conditions in the group investigated.

The analgesic schemes were submitted to the CEA and the results were expressed as a quotient in which the numerator was the cost of the therapy estimated for 100 patients and the denominator was the effectiveness estimated according to the above criteria. The efficiency of one analgesic scheme in relation to the other was compared by applying mean and incremental cost-effectiveness analysis. We used sensitivity analysis and modified the effectiveness of the analgesic schemes on the basis of the pain-expressing behavior of the patients under study.

\section{RESULTS}

The compositions of the therapeutic schemes were different, with 4 of them consisting of combinations of analgesic, i.e., the so-called multimodal schemes (A), (B), (D), (E) and 1 of them being unimodal (C). It can be seen that among the 5 schemes, there are 3 analgesics combined in different manners. Schemes (A), (B) and (D) were administered orally and IM, and (C) and (E) were administered orally (Table 1 ).
Table 1 - Composition and posology of the analgesic schemes applied to the patients on the 1stPo. São Paulo, 2002

\begin{tabular}{|c|c|c|c|c|c|}
\hline $\begin{array}{l}\text { Analgesic } \\
\text { scheme }\end{array}$ & $\begin{array}{c}\text { c Active principle of } \\
\text { the analgesic }\end{array}$ & $\begin{array}{c}\text { Prescribed } \\
\text { dose }\end{array}$ & $\begin{array}{c}\text { Route of } \\
\text { administration }\end{array}$ & $\begin{array}{l}\text { Frequency } \\
\text { of use }\end{array}$ & $\begin{array}{l}\text { Patients } \\
\mathrm{N}=89\end{array}$ \\
\hline \multirow[t]{3}{*}{ (A) } & Codeine + & $30 \mathrm{mg}$ & VO & $6 / 6 \mathrm{hs}$ & 42 \\
\hline & Acetaminophen * & $500 \mathrm{mg}$ & & & \\
\hline & Ketoprofen & $100 \mathrm{mg}$ & $\mathbb{M}$ & $12 / 12 \mathrm{hs}$ & \\
\hline \multirow[t]{3}{*}{ (B) } & Codeine + & $30 \mathrm{mg}$ & VO & $8 / 8 \mathrm{hs}$ & 14 \\
\hline & Acetaminophen * & $500 \mathrm{mg}$ & & & \\
\hline & Ketoprofen & $100 \mathrm{mg}$ & $\mathbb{M}$ & $12 / 12 \mathrm{hs}$ & \\
\hline (C) & Ketoprofen & $100 \mathrm{mg}$ & Vo & $8 / 8 \mathrm{hs}$ & 13 \\
\hline \multirow[t]{3}{*}{ (D) } & Propoxyphene & $77 \mathrm{mg}$ & vo & $8 / 8 \mathrm{hs}$ & 10 \\
\hline & + aspinin & $325 \mathrm{mg}$ & & & \\
\hline & Ketoprofen & $100 \mathrm{mg}$ & $\mathbb{M}$ & $12 / 12 \mathrm{hs}$ & \\
\hline \multirow[t]{2}{*}{ (E) } & Codeine + & $30 \mathrm{mg}$ & VO & $6 / 6$ hs & 10 \\
\hline & Acetaminophen * & $500 \mathrm{mg}$ & & & \\
\hline
\end{tabular}

* Combination of the active principles in the composition of the analgesic.

The (D) scheme presented the highest cost (\$ 96,97) when treatment failure occurred (SRT+PRN). The (C) scheme $(\$ 51,04)$ showed the lowest cost compared to the combined treatments but also showed the highest probability $(0.77)$ of the occurrence of treatment failure. When the costs of the two regimes (SRT and PRN) were summed and multiplied by the probabilities (Did not use PRN and Used PRN), the (A) scheme was found to present the highest cost $(\$ 80,47)$ and (C) the lowest $(\$ 45,66)$ (Table 2).

Table 2 - Estimated costs of the analgesic scheme as used on the 1stPO. São Paulo, 2002

\begin{tabular}{cccccccc}
\hline $\begin{array}{c}\text { Analgesic } \\
\text { scheme }\end{array}$ & \multicolumn{2}{c}{ Cost (U\$) } & \multicolumn{2}{c}{ Probability (p) } & \multicolumn{2}{c}{$\begin{array}{c}\text { Cost of the scheme } \\
\text { (per patient) }\end{array}$} \\
& $\begin{array}{c}\text { SRT } \\
\text { (success) }\end{array}$ & $\begin{array}{c}\text { SRT+PRN } \\
\text { (failure) }\end{array}$ & $\begin{array}{c}\text { Did not } \\
\text { use PRN }\end{array}$ & $\begin{array}{c}\text { Used } \\
\text { PRN }\end{array}$ & & Cost x p & (COST x p) \\
\hline (A) & 66.32 & 89.93 & 0.40 & 0.60 & 26.5253 .95 & 80,47 \\
(B) & 56.80 & 95.67 & 0.43 & 0.57 & 24.4254 .53 & 78,95 \\
(C) & 27.66 & 51.04 & 0.23 & 0.77 & 6.36 & 39.30 & 45,66 \\
(D) & 52.10 & 96.97 & 0.40 & 0.60 & 20.8458 .18 & 79,02 \\
(E) & 38.06 & 77.61 & 0.50 & 0.50 & 19.03 & 38.80 & 57,83 \\
\hline
\end{tabular}

The mean cost-effectiveness obtained for the five schemes, indicating that (C) was of low cost and of reduced effectiveness and (B) was of high cost and of low effectiveness. (A) was of higher cost and of lower effectiveness compared to (E). The (E) scheme presented the lowest cost $(\$ 192,76)$ per patient without breakthrough pain episodes during the $24 \mathrm{~h}$ of the 1stPO. The (C) scheme showed the worst relationship, with a cost of $\$ 592,98$ for each patient without a breakthrough pain episode (Table 3 ). 
Table 3 - Cost, effectiveness and cost-effectiveness ratio for the analgesic schemes used on the 1stPo day. São Paulo, 2002

\begin{tabular}{cccc}
\hline $\begin{array}{c}\text { Analgesic } \\
\text { scheme }\end{array}$ & Cost (U\$) & $\begin{array}{c}\text { Effectiveness: } \\
\text { (Proportion of patients } \\
\text { with no breakthrough } \\
\text { pain episodes) }\end{array}$ & $\begin{array}{c}\text { Cost-Effectiveness: } \\
\text { (per patient with no } \\
\text { breakthrough pain } \\
\text { episodes) }\end{array}$ \\
\hline (A) & $8,047.00$ & 26.20 & 307.13 \\
(B) & $7,895.00$ & 14.30 & 552.09 \\
(C) & $4,566.00$ & 7.70 & 592.98 \\
(D) & $7,902.00$ & 30.00 & 263.40 \\
(E) & $5,783.00$ & 30.00 & 192.76 \\
\hline
\end{tabular}

Table 4 shows that, according to scenario 1 , the (D) and (E) schemes presented similar effectiveness $(43.0 \%)$, while the (C) scheme was the worst $(33.0 \%)$. It can also be seen that the recalculated mean cost-effectiveness of (E) (\$ $134,48)$ corresponded to the lowest cost per patient without a breakthrough pain episode, followed by (C) (\$138,36). The (A) scheme $(\$ 206,33)$ presented the lowest ratio. In scenario 2 , the (D) scheme was the most effective (28.0\%) and the (A) scheme showed the worst effectiveness (3.0\%). It can be seen that when the mean cost-effectiveness of the schemes was recalculated, (C) $(\$ 413,07)$ showed the best ratio and $(\mathbf{A})$ the worst, demonstrating a cost of $\$ 2.682,33$ per patient who presented 3 or more breakthrough pain episodes.

Table 4 - Analysis of the sensitivity of costeffectiveness with respect to the modifications of the effectiveness variable. São Paulo, 2002

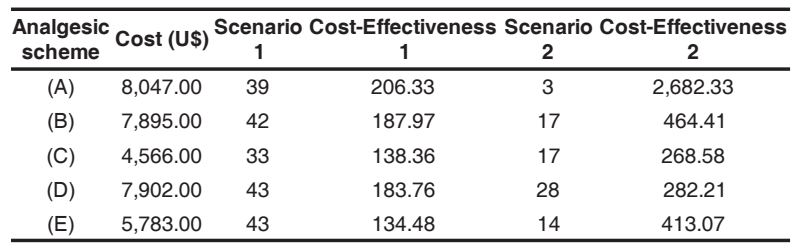

Original scenario - No of patients who did not present breakthrough pain episodes/total $N^{0}$ of patients

Scenario 1 - No of patients who presented a maximum of 1 breakthrough pain episode/total $\mathrm{N}^{\circ}$ of patients

Scenario 2 - No of patients who presented 3 or more breakthrough pain episodes/total total $\mathrm{N}^{\circ}$ of patients

\section{DISCUSSION}

The emphasis on cost containment and on improved efficiency of the health system has created the explicit need to quantify and justify the costs and benefits related to specific therapies so that more rational therapeutic decisions may be made. Thus, a worldwide increase in assessment studies has been observed, with the use of economic techniques for the comparison of different treatment alternatives.

With respect to the costs of the therapeutic schemes used during the 1stPO, the (A) scheme differed from the others in terms of cost and frequency of use, with acetaminophen + codeine and ketoprofen being administered 4 times $(6 / 6 \mathrm{~h})$ and 3 times a day $(8 / 8 \mathrm{~h})$, respectively. These results permit us to infer that the frequency of administration is an important factor in the cost of therapy. Studies with other medications have also demonstrated that when the cost of the time spent by the nursing team in the administration of the medication is included, the frequency of daily use is definitely a factor that interferes with the cost of treatment ${ }^{(3-5)}$.

Hospitals in general have been concerned with the outcome of analgesic therapy in addition to its cost since pain is one of the most frequent symptoms in the services, and is the subject of constant outcome evaluation of the services by the Joint Commission on the Accreditation of Healthcare Organizations - JCAHO. One of the norms of JCAHO concerns the right of the patient to receive effective pain management as a way of guaranteeing quality of care ${ }^{(12)}$. Thus, considering that the objective of analgesic therapy during the PO period is to control pain and that the CEA of therapeutic schemes is preceded by the identification of the outcome on the basis of which relative effectiveness should be measured, the criteria was established based on the real parameters available at the site of investigation, exactly because this was a study focusing on effectiveness and not on efficacy.

The CEA was expressed by the costeffectiveness relation, i.e., by the benefit conferred by the therapeutic strategy used under routine clinical practice conditions $^{(9-10)}$. The CEA showed that the (C) scheme expressed the worst cost-effectiveness ratio, with a cost of $\$ 592,98$ per patient without a breakthrough pain episode. The (E) scheme presented the lowest cost per effectiveness unit, which represents the best cost-effectiveness relationship, i.e., \$192,76 per patient with no breakthrough pain episode. These results confirm literature recommendations which state that multimodal schemes are more effective for the treatment of PO pain ${ }^{(2,8,13-14)}$.

Application of sensitivity analysis by varying the scenarios of effectiveness demonstrated that, in scenario 1, the (E) and (D) schemes showed similar effectiveness $(43.0 \%)$, confirming the original results 
of the study. When the mean cost-effectiveness of the schemes was calculated, the original result was confirmed for scenario 1 , confirming the solidity of the conclusions initially drawn. In view of these results, we may infer that for "less serious" patients, i.e., the patients who presented up to 1 breakthrough pain episode, the (E) scheme represents a good therapeutic option.

The main contribution of the present study was to introduce economic rationality among health professionals, especially in Brazilian hospitals, not in order to replace clinical rationality, but to integrate the two. In practice, this combination has yielded good results in developed countries, serving as support of technical and administrative decisions and showing how therapeutic needs can be reconciled with the possibility of covering the costs in the decision making process.

However, the study has limitations that should be pointed out so that others will be able to reduce or remedy them. This was a retrospective investigation that, even though it used information from the medical records, which indeed was the expression of the events that occurred, caused the investigators to work with previously recorded information. In this type of investigation it is not possible to consider the results of costs and effectiveness to be representative. It is a study centered on a particular hospital with its own characteristics and the sample size does not permit to make inferences, especially regarding the effectiveness in groups of hemorrhoidectomized patients from other hospitals.

Concerning to the costs of producing services, in any economic evaluation, only the site under study can be evaluated since these services vary from one hospital to another. Cost analysis involved only the direct costs estimated from official market prices and not the real costs for the institution. In the estimate of the direct costs of analgesic therapy, the study was limited to the categories of medications, materials, maintenance of venous access and nursing work, without incorporating other costs relevant to therapy such as the costs of the side effects of analgesics.

Indirect, rather than direct, determination was used for the assessment of the effectiveness of analgesia schemes. The use of instruments for pain assessment would definitely provide more precise measures of therapeutic success. Thus, the conclusion drawn from this study, whether concerning cost or effectiveness, should not be generalized but further studies are suggested in order to support, complement or refute the present results.

Despite the limitations, the cost-effectiveness data showed that codeine $120 \mathrm{mg}+$ acetaminophen $2000 \mathrm{mg}$ was the most effective therapy with the lowest cost per patient without breakthrough pain episodes $(\$ 65,23)$.

\section{REFERENCES}

1. Ashburn MA, Ready LB. Postoperative pain. In: Loeser JD, Butler S, Chapman CR, Turk DC (ed.). Bonica's management of pain. Philadelphia: Lippincott Willims \& Wilkins, 2001. p. 765-79. 2. McCaffery M, Ferrell BR. Nurse's knowledge of pain assessment and management: how much progress have we made? J Pain Symptom Manag 1999; 14(3):175-88.

3. Secoli SR, Padilha KG, Litvoc J, Peniche ACG. Dor pósoperatória: o custo da terapia analgésica. Rev SOBECC 2006; 11(2):39-44.

4. Choinière $M$, Rittenhouse $B E$, Perreault $S$, Chartrand $D$, Rousseau $P$, Smith B et al. Efficacy and costs of patientcontrolled analgesia versus regulary administered intramuscular opioid therapy. Anesthesiology 1998; 89(6):1377-88.

5. Chang AM, Ip WY, Cheung TH. Patient-controlled analgesia versus intramuscular injection: a cost effectiveness analysis. J Adv Nurs 2004; 46(5):531-41.

6. Viscusi ER, Schechter LN. Patient-controlled analgesia: finding a balance between costs and confort. Am J Health Syst Pharm 2006; 63(8 Suppl 1):S3-13.
7. Chaves LD, Pimenta CAM. Controle da dor pós-operatória: comparação entre métodos analgésicos. Rev Latino-am Enfermagem 2003; 11(2):215-9.

8. Rainer TH, Jacobs P, Ng YC, Cheung NK, Tam M, Lam PKW et al. Cost effectiveness analysis of intravenous ketorolac and morphine for treating pain after limb injury: double blind randomized controlled trial. BMJ 2000; 321(7271): 1427-51. 9. Drummond MF. Guidelines for pharmacoeconomics studies. The ways forward. Pharmacoeconomics 1994; 6(6):493-7. 10. Hay JW. Evaluation and review of pharmacoeconomic models. Expert Opin Pharmacother. 2004; 5(9):1867-80.

11. Guia farmacêutico Brasíndice. São Paulo: Andrei Publicações Médicas, Farmacêuticas e Técnicas; 2002. 198 p.

12. Joint Commission on the Accreditation of Healthcare Organizations: Hospital Accreditation Standards. Oakbrook Terrace, IL: JCAHO, 2001.

13. Newton SE, Robinson J, Kozac J. Balanced analgesia after hysterectomy: the effect on outcomes. Medsurg Nurs 2004; 13(3):176-80.

14. Kehlet $\mathrm{H}$. Multimodal approach to control postoperative pathophysiology and rehabilitation. $\mathrm{Br}$ J Anaesthesiol 1997; 78(5):606-17. 